NBER WORKING PAPER SERIES

CHANGING FACULTY EMPLOYMENT AT FOUR-YEAR COLLEGES AND UNIVERSITIES IN THE UNITED STATES

\author{
Liang Zhang \\ Ronald G. Ehrenberg \\ Xiangmin Liu \\ Working Paper 21827 \\ http://www.nber.org/papers/w21827 \\ NATIONAL BUREAU OF ECONOMIC RESEARCH \\ 1050 Massachusetts Avenue \\ Cambridge, MA 02138 \\ December 2015
}

The Cornell Higher Education Research Institute (CHERI) received financial support from the Andrew W, Mellon Foundation, however all of the conclusions expressed in the paper are strictly our own. The views expressed herein are those of the authors and do not necessarily reflect the views of the National Bureau of Economic Research.

NBER working papers are circulated for discussion and comment purposes. They have not been peerreviewed or been subject to the review by the NBER Board of Directors that accompanies official NBER publications.

(C) 2015 by Liang Zhang, Ronald G. Ehrenberg, and Xiangmin Liu. All rights reserved. Short sections of text, not to exceed two paragraphs, may be quoted without explicit permission provided that full credit, including $(\mathrm{C}$ notice, is given to the source. 
Changing Faculty Employment at Four-Year Colleges and Universities in the United States Liang Zhang, Ronald G. Ehrenberg, and Xiangmin Liu

NBER Working Paper No. 21827

December 2015

JEL No. I23,J23

\begin{abstract}
$\underline{\text { ABSTRACT }}$
We use panel data models to examine variations and changes over time in faculty employment at four-year colleges and universities in the United States. The share of part-time faculty among total faculty has continued to grow over the last two decades, while the share of full-time lecturers and instructors has been relatively stable. Meanwhile, the share of non-tenure track faculty among faculty with professorial ranks has been growing. Dynamic panel data models suggest that employment levels of different types of faculty respond to a variety of economic and institutional factors. Colleges and universities have increasingly employed faculty whose salaries and benefits are relatively inexpensive; the slowly deteriorating financial situations at most colleges and universities have led to an increasing reliance on a contingent academic workforce.
\end{abstract}

Liang Zhang

410B Rackley Building

Penn State University

University Park, PA 16803

1xz19@psu.edu

Ronald G. Ehrenberg

Cornell Higher Education Research Institute

271 Ives Hall East

Ithaca, NY 14853-3901

and NBER

rge2@cornell.edu
Xiangmin Liu

508E Keller Building

Penn State University

University Park, PA 16802

xul16@psu.edu 


\section{Changing Faculty Employment at Four-Year Colleges and \\ Universities in the United States}

\section{Introduction}

The landscape of faculty employment in higher education has evolved at least in two ways, namely, employment status (i.e., full-time vs. part-time) and tenure eligibility. Many have observed that in response to the oversupply of PhDs in many academic disciplines since the early 1970s, a segmented academic employment structure evolved consisting of tenure track and nontenure track faculty (Roemer \& Schnitz 1982; Rosenblum \& Rosenblum 1990), with the majority of non-tenure track faculty working part-time and most tenure-track faculty working full-time. Gradually, this bifurcated system based on tenure status transformed into a trifurcated one, consisting of full-time faculty who were tenured or on tenure tracks, full-time faculty who were not eligible for tenure, and part-time faculty (Ehrenberg 2012; Schuster 1998). Among full-time faculty, tenure eligibility roughly aligned with academic ranks, with professorial faculty (i.e., assistant, associate, and full professors) typically tenured or tenure-eligible, and instructors and lecturers not on tenure tracks. While some professorial faculty were not on tenure tracks, they were certainly not the norm.

This seems not to be the case any longer. The line between professorial ranks and tenure eligibility has become increasingly blurred. Recent data indicate that while the share of full-time instructors and lecturers has stagnated, the share of professorial faculty who are not eligible for tenure has increased substantially. This has occurred across all professorial ranks, although most prominently among assistant professors. With this new growth, non-tenure track faculty, including part-time faculty and full-time non-tenure track faculty, now constitute the majority of the academic labor force in the United States (Kezar \& Sam 2010). Some argue that institutions 
have been actively adjusting their faculty employment strategies in order to cope with stringent fiscal realities, increase managerial discretion, and maintain an academic workforce that is responsive to market incentives (Rhoades 1998; Zhang \& Liu 2010).

While much has been written about the growth of contingent faculty employment in higher education, very few have documented the recent growth in the share of non-tenure track professorial faculty and used panel data to examine various economic and institutional factors behind this trend. In this study, we use faculty employment data from four-year colleges and universities in the United States from1993 to 2013 and document recent trends in faculty employment, especially the increasing share of professorial faculty who are not tenure eligible. We then examine an array of economic and institutional characteristics that affect the employment of different types of faculty in terms of employment status, tenure eligibility, and faculty ranks across different types of institutions over time.

\section{Literature Review}

The use of contingent faculty at colleges and universities in the United States has been rising since 1970s; at the same time, the types of faculty that constitute the "contingent" academic workforce have become increasingly complex. In the traditional dual labor market model, part-time faculty represented the primary type of contingent faculty as opposed to fulltime regular faculty who were tenured or on tenure tracks. In 1975, part-time faculty represented about 30\% of the academic labor force in the United States; by 2005, this proportion had increased to approximately 48\% (Monks 2009), ${ }^{1}$ a proportion much higher than in the rest of the U.S. workforce. This appeared to be an anomaly, considering the high skill requirements and

\footnotetext{
${ }^{1}$ As we show later in this paper, the proportion of part-time faculty has continued to increase, albeit slowly, in recent years.
} 
institutionalized practice of tenure in the academic labor market. Many argued that the rise of part-time faculty employment was due to an oversupply of PhDs in many academic fields since the 1970s (Roemer \& Schnitz 1982; Rosenblum \& Rosenblum 1990).

While the proportion of full-time faculty shrunk due to increased employment of parttime faculty, the composition of full-time faculty became increasingly stratified. During the 1980s and 1990s, there was tremendous growth in the share of teaching faculty with lecturer and instructor titles among full-time faculty. Ehrenberg and Zhang (2005) reported that the proportion of teaching faculty with lecturer and instructor titles among all full-time faculty increased from about $10 \%$ in 1987 to $22 \%$ in 2005 , a trend that was consistently documented in the literature (e.g., Anderson 2002; Conley \& Lesley 2002; Zhang \& Liu 2010). From a job security perspective, some full-time lecturers and instructors have multi-year contracts that distinguish them from part-time faculty with limited duration contracts. However, because the vast majority of full-time lecturers and instructors are not tenure-eligible, they are denied the ultimate insurance of job security. Probably for these reasons, in empirical studies on faculty employment, researchers typically viewed these full-time teaching faculty as part of the contingent workforce in higher education.

Not surprisingly, as the proportion of part-time faculty and full-time teaching faculty rose, the proportion of full-time professorial faculty (i.e., those with assistant, associate, and full professor ranks) declined. Traditionally, professorial faculty were either tenured or on tenure tracks, which ensured lifelong employment, as opposed to the unstable or fixed-term employment situations of part-time faculty and full-time lecturers and instructors. Furthermore, professors were usually evaluated based on research productivity and teaching effectiveness. In contrast, part-time faculty and full-time lecturers and instructors were hired primarily to teach; in 
most cases, research was not part of their job descriptions (Anderson 2002; Ehrenberg \& Zhang 2005; Gappa \& Leslie 1993; Zhang \& Liu 2010).

In recent years, however, there has been a slow but steady erosion of tenure within the full-time professorial ranks. Many professors are now hired without tenure eligibility. Anecdotal evidence suggests that this has occurred for various reasons. For example, on the research side, non-tenure track research professors often hold soft-money positions, which offer advantages of low or no teaching responsibilities but require them to underwrite at least a share of their own salaries. As a result, employing a large number of research professors would enable institutions to generate a high volume of external grants and contracts and be responsive to a volatile funding environment.

On the teaching side, some institutions are now creating career paths for non-tenure track professorial faculty as they begin to recognize the importance of instructional faculty. For example, using undergraduate student transcript data from Northwestern University, Figlio, Schapiro and Soter (2013) showed that non-tenure track faculty outperform tenure track faculty in terms of student learning in core classes, which is mostly attributed to long-term employment relationships with full-time non-tenure track faculty, a pattern similar to what Bettinger and Long (2010) found in their study using student transcript data from large public institutions in Ohio. Not surprisingly, Northwestern now has the titles of assistant, associate, and full professors of instruction. As non-tenure track assistant professors mature (are promoted), growth is expected in the ranks of non-tenure track associate and full professors.

Finally, some institutions now use the title professor of practice when hiring faculty from outside academia with unique skills. Previously non-academic faculty members were hired as senior lecturers, but many institutions found that the title was not sufficiently prestigious to 
attract top talent. Over time, more growth can also be expected in the senior non-tenure track professorial faculty ranks.

What can economic theories inform us about these trends? The basic "law" of labor demand suggests a negative relationship with the costs of employing a specific type of faculty, and a positive relationship with the costs associated with employing other types of faculty. For example, other factors held constant, if salaries paid to professorial faculty rose relative to parttime faculty, institutions would hire fewer professorial faculty and more part-time faculty, which is essentially a cost-saving mechanism. Empirical results are consistent with these theoretical predictions. Zhang and Liu (2010) used a cross-sectional sample of four-year colleges and universities and confirmed substitution effects among part-time faculty, full-time teaching faculty, and full-time professorial faculty. In addition, Cheslock and Callie (2015) used detailed salary and employment information from a sample of business schools and found that as salaries grew for professors, their employment level decreased.

Costs must be cut in times of financial instability and declining public support in the form of state appropriations and government grants and contracts. However, the substantial gap in salary and benefits between contingent faculty and their tenured and tenure track counterparts may motivate contingent faculty to unionize and negotiate their employment conditions with institutions. ${ }^{2}$ Once unionized, faculty unions can influence salary and job security. Research has shown that the presence of faculty unions is positively associated with salary premiums (Hedrick, Henson, Krieg, and Wassell 2011). The effect of faculty unions on employment levels is, however, not straightforward. Take full-time, non-tenure track faculty unions, for example. On the one hand, these faculty unions seek to increase salaries, protect job security, and maintain

\footnotetext{
${ }^{2}$ See Maynard and Joseph (2008) and Liu and Zhang (2015) for detailed discussions on job satisfaction and work. effort of contingent faculty.
} 
faculty participation in shared governance structures (Rhoades 1998); thus, they may be opposed to the employment of part-time faculty if they believe doing so will erode employment stability for full-time faculty. On the other hand, the presence of these unions, which may increase fulltime non-tenure track faculty, may also increase an institution's reliance on part-time faculty. Similarly, while the presence of part-time faculty unions may discourage institutions from hiring more part-time faculty, it may help universities attract and recruit high-quality instructors by improving their working conditions.

Institutional wealth also affects faculty employment. The "income effect" on different types of faculty employment depends on roles of each type of faculty in improving institutional outcomes as perceived by institutions. As far as institutional prestige is concerned—which is increasingly defined by research as opposed to teaching—colleges and universities would most likely employ fewer part-time faculty and full-time teaching faculty and more professorial faculty when financial resources permit. Of course, it is also true that employing more part-time and full-time teaching faculty to fulfill teaching needs would free up time for professorial faculty to conduct research (Zhang \& Ehrenberg 2010).

In addition to price and income effects, faculty employment at colleges and universities is influenced by a host of institutional characteristics (Liu \& Zhang 2013). Private institutions, on average, have higher levels of part-time faculty than their public counterparts. Furthermore, institutions located in big cities or suburbs are able to draw on a large supply of qualified individuals for part-time work. The proportion of part-time students also is positively associated with part-time faculty employment. Finally, the difference in faculty employment across institutions is related to the portfolio of academic programs (Johnson \& Turner 2009). Although we do not examine many of these factors in our panel data analysis because they are superseded 
by institutional fixed effects, we do examine the effects of time-variant factors on faculty employment.

\section{Data}

The main data source for this study was the Integrated Postsecondary Education Data System (IPEDS). ${ }^{3}$ We collected data on faculty employment and other institutional characteristics for academic years 1993-94 through 2013-14. We limited our sample to fouryear general colleges and universities, a total of 1,463 institutions; we excluded institutions offering less than four-year degrees and specialized institutions from the analysis. Because degree programs offered by institutions changed slightly over years, we used information on level of instruction, i.e., four-year general colleges and universities based on data reported in academic year 2013-14 to determine our final sample. In other words, a few institutions in our sample were not four-year colleges in earlier years.

We set the beginning of our study period to 1993-94 because that was the first year the IPEDS Fall Staff Survey provided detailed information on employment status (part-time vs. fulltime), academic ranks (assistant professor, associate professor, full professor, lecturer and instructor), and tenure status (tenured and tenure track, and non-tenure track). These data, however, were only available in odd-numbered years between 1993 and 2001. Since 2001, institutions were encouraged, but not required, to report these detailed data in even-numbered years. Finally, there was a change in the definition of instructional faculty between the 2011-12 and 2012-13 academic years. Prior to the 2012-13 academic year, instructional faculty reported

\footnotetext{
${ }^{3}$ IPEDS consists of a series of interrelated survey components that are designed to collect information about different aspects of postsecondary educational institutions, including institutional characteristics, student enrollment and completion rates, institutional finances, and faculty employment and compensation. IPEDS collects data from all post-secondary institutions in the United States and territories.
} 
in IPEDS included faculty members whose main responsibilities were instruction, research, and/or public services. Since then, instructional faculty only include faculty whose main responsibility is instruction. Due to this change of definition, we excluded the last two years of data in our regression models.

In Table 1, we provide information on the variables used in this study. In addition to faculty employment data by employment status, rank, and tenure status, we also used faculty salary data to compute the average salary for professorial faculty and for instructors and lecturers. In some model specifications, we estimated professorial faculty by ranks, so average salaries were also computed for subcategories of professorial faculty. IPEDS salary data did not include salary data for part-time faculty because part-time faculty were usually paid on a per course basis, making it difficult to report and compare across institutions since workloads for part-time faculty varied. To estimate the income effect, we collected data on total current revenues, adjusted by full-time equivalent (FTE) student enrollment depending on model specifications.

We also examined the effects of institutional characteristics on faculty employment. These variables include enrollment size, the proportion of part-time students, institutional control, Carnegie classification, and whether an institution had a medical school. These variables have been used in the literature as important determinants of faculty employment. Since some of these variables are time invariant, they are suppressed in panel data models. Finally, we used faculty union data from the Directory of Faculty Contracts and Bargaining Agents in Institutions of Higher Education 2012, compiled by the National Center for the Study of Collective Bargaining in Higher Education and the Professions. We created three dummy variables to represent whether an institution had a full-time tenure-track union, a full-time non-tenure track union, and a parttime non-tenure track union in each year. 


\section{Trends of Faculty Employment}

Table 2 reports the shares of part-time faculty, full-time lecturers and instructors, and professorial faculty by type of institutional control and Carnegie classification. ${ }^{4}$ Because the definition of instructional faculty changed in 2012-13, we use data from 2011-12 as our most recent data points in order to make comparisons with earlier years. Several observations can be made here. First, the variation in faculty composition across institutional types is substantial. For example, in 1993-94, the proportions of part-time faculty ranged from a low of $19.4 \%$ at public doctoral/research institutions to a high of $51.8 \%$ at private master's institutions. ${ }^{5}$ Also, based on the standard deviations reported in parentheses, it is clear that faculty composition varied within each category of institutions. Second, generally speaking, private institutions employed more contingent faculty than their public counterparts (i.e., almost 50\% private vs. $35 \%$ at public institutions). This is true except for bachelor's institutions, where public institutions had a higher proportion of contingent faculty than their private counterparts. Third, among public institutions, doctoral/research institutions had the highest proportion of professorial faculty while bachelor's institutions had the highest proportion of contingent faculty, In contrast, among private institutions, doctoral/research institutions and bachelor's institutions had the highest proportion of full-time professorial faculty. Finally, from 1993 to 2011, there was a significant increase in the proportion of part-time faculty and a significant decrease in the proportion of full-time

\footnotetext{
${ }^{4}$ Carnegie classification is based on the 2010 edition (Carnegie Foundation for the Advancement of Teaching, 2011). The numbers of institutions listed in this table are based on all institutions that were included in each category in 2010. The actual numbers used to compute the proportions in the table may differ due to missing data. However, using a consistent sample of institutions in 1993 and 2013 yielded very similar results. This sample provides us with a relatively homogenous group of institutions with sufficient variation in faculty employment. We do not include baccalaureate/associate's colleges, theological institutions, or specialized schools and centers because these institutions usually have different faculty employment practices than general purpose colleges and universities. ${ }^{5}$ Our sample does not include two-year colleges, where proportions of part-time faculty and full-time non-tenure track faculty are much higher than those at four-year institutions.
} 
professorial faculty. The proportion of full-time lecturers and instructors remained relatively stable over the study period, at around $11 \%$ of total faculty. ${ }^{6}$ The shift from full-time professorial faculty to part-time faculty seems to be more pronounced among public institutions than among private institutions. This is consistent with the view that declining public support for higher education has propelled colleges and universities to use part-time faculty as a cost-saving strategy.

\section{[INSERT TABLE 2 ABOUT HERE]}

Figure 1 shows the trend of faculty employment during the study period. The graph indicates a consistent increase in part-time faculty and a steady decrease in professorial faculty over time, while the proportion of full-time lecturers and instructors remained quite stable. The break in the trend line between 2011 and 2012 is due to the change in the definition of instructional faculty in the Fall Staff Survey, which excluded faculty members whose main responsibility was research and public service and restricted the category to faculty whose main responsibility was instruction. Because part-time faculty members are hired mainly for the purpose of teaching, their proportion was higher after 2011.

\section{[INSERT FIGURE 1 ABOUT HERE]}

The change in the distribution of faculty among part-time faculty, full-time lecturers and instructors, and professorial faculty is related to, but different from the change in the distribution of faculty employment by tenure status due to the change in tenure eligibility among full-time faculty. Table 3 reports the share of non-tenure track full-time faculty by academic rank for each type of institution. First, across different academic ranks, there is a clear divide between full-time

\footnotetext{
${ }^{6}$ This trend differs from earlier studies (e.g., Anderson 2002; Conley \& Lesley 2002; Ehrenberg \& Zhang 2005; Zhang \& Liu 2010) because researchers used the total number of full-time faculty as the denominator to calculate the share of full-time teaching faculty, while we used the total number of faculty, both part-time and full-time, to compute this proportion.
} 
lecturers/instructors and professorial faculty. While the (vast) majority of lecturers and instructors were not tenure eligible, the reverse was true for all three ranks of full-time professorial faculty. This is not surprising, given the job descriptions for teaching faculty and tenure criteria at most four-year colleges and universities. Among the three professorial ranks, assistant professors had the highest proportion and full professors had the lowest proportion of faculty who were not tenure eligible. Second, tenure eligibility of lecturers and instructors seems to be related to the level of institutional emphasis on instruction. For example, private institutions, on average, had higher proportions of lecturers and instructors who were tenure eligible, reflecting their desire to maintain a stable, effective instructional faculty. In addition, among both public and private institutions, bachelor's institutions had the highest proportion of teaching faculty eligible for tenure. This was true in both 1993 and 2011, although the difference was not as pronounced in the latter year.

\section{[INSERT TABLE 3 ABOUT HERE]}

Finally, from 1993 to 2011, there was a significant increase in the proportions of all ranks of full-time, non-tenure track faculty. For all four-year institutions, $22.4 \%$ of all full-time faculty were not eligible for tenure in 1993; this proportion increased to 34.0\% in 2011. Broken down by rank, the proportions in 1993 were 80\%, 23.7\%, 8.9\%, and 5.0\% for lecturers/instructors, assistant professors, associate professors, and full professors, respectively. These proportions increased across the board to $94.7 \%, 35.6 \%, 15.9 \%$, and $9.7 \%$ in 2011 . Aggregating across professorial faculty, the proportion not eligible for tenure increased from $12.1 \%$ in 1993 to 20.3\% in 2011 (these two proportions are not reported in the table). So, roughly speaking, 1 out of every 5 professors was not eligible for tenure in 2011; for assistant professors the ratio was 1 out of every 3. 
Figure 2 shows the trend of tenure eligibility by faculty rank during the study period. The graph indicates a gradual but steady increase in the proportion of non-tenure track full-time faculty over time for all ranks of full-time faculty. Despite the clear divide between lecturers/instructors and professors, a significant proportion of professorial faculty, especially assistant professors, were not on tenure tracks in 2011. Not surprisingly, when only instructional faculty data are considered in the last 2 years of the study period in Figure 2, the proportion of professorial faculty who were not on tenure tracks becomes lower, suggesting a high proportion of professorial faculty who were not eligible for tenure in research and public service positions.

\section{[INSERT FIGURE 2 ABOUT HERE]}

\section{Econometric Analysis}

In this section, we present a formal regression analysis to examine how faculty employment is influenced by various economic and institutional factors. We consider a dynamic panel data model where the employment levels of different types of faculty depend on each other. In other words, if the faculty employment in category $i$ in one year is high, it affects faculty employment in subsequent years not only in category $i$, but also in other categories. One of the empirical decisions is how many categories of faculty employment to estimate separately. The basic categories examined in the literature include part-time faculty, full-time lecturers/instructors, and professorial faculty; however, based on the time trends we identified in the proceeding section, it appeared appropriate to separate assistant professors from associate and full professors. Nearly every 1 out 3 assistant professors in recent years was not on a tenure track, while the proportion was much lower among associate and professors. In addition, assistant professors, even those on tenure tracks, have much less job security than tenured 
associate and full professors. For these reasons, employment decisions related to assistant professors are probably quite different than those related to their more senior counterparts.

Formally, we consider four mutually-exclusive faculty types in our empirical model: parttime faculty, full-time lecturers/instructors, assistant professors, and associate and full professors. ${ }^{7}$ Take part-time faculty as an example. The number of part-time faculty at institution $i$ in year $t\left(P T_{i t}\right)$ is specified to be a function of employment of each of the four faculty types in year $t-1\left(F a c_{i j, t-1}\right)$; the average salary of each of the three full-time faculty types for which we have data in year $t\left(F_{a c} S_{S a l}{ }_{i j t}\right)$; institutional revenue in year $t\left(\operatorname{Rev}_{i t}\right)$; and a vector of institutional characteristics including, for example, enrolment $\left(X_{i t}\right)$, institutional fixed effects $\left(\eta_{i}\right)$, time fixed effects $\left(\theta_{t}\right)$, and a random error term $\left(\mu_{i t}\right)$ :

$P T_{i t}=\alpha_{0}+\sum_{j=1}^{4} \alpha_{1 j} F c_{i j, t-1}+\sum_{j=2}^{4} \alpha_{2 j} F_{a c_{-}} S_{a l} l_{i j t}+\alpha_{3} \operatorname{Rev}_{i t}+X_{i t} \beta+\eta_{i}+\theta_{t}+\mu_{i t}$ (Eq. 1) where $j=1,2,3,4$, representing part-time faculty, full-time lecturers/instructors, assistant professors, and associate and full professors, respectively. The same equation can be estimated for each of the four faculty types. Institutional fixed effects control for variables not included in the model that are relatively fixed over time and might be expected to influence faculty employment levels (e.g., institutional control, Carnegie classification, institutional location, etc.). Likewise, time fixed effects control for national level variables that vary over time that might influence an institution's employment decisions (e.g., the supply of PhDs, unemployment rate, etc.). Since the error terms could be autoregressive (i.e., institutions that employ a higher or lower number of certain types of faculty in one time period are likely to employ a higher or lower number of those types of faculty in the next period), the above model is estimated using

\footnotetext{
${ }^{7}$ Unfortunately, although IPEDS reports data on average salary for full-time faculty by ranks, these data are not available for part-time faculty or full-time faculty by tenure status.
} 
dynamic panel data modeling techniques (Arellano \& Bond 1991). Statistical tests suggest that one lag term is sufficient to account for the autoregressive nature of error terms.

Table 4 presents results from Eq. 1; values for the dependent variables are the logarithms of the numbers of part-time faculty, full-time lecturers and instructors, assistant professors, and associate and full professors, respectively. Because faculty employment data are only available for odd-numbered years between 1993 and 2001, we only use data from 2001-2011 in our empirical models. First, these models estimate how previous levels of faculty employment affected recent levels. Not surprisingly, all four estimated coefficients on the diagonal line are large and significant, suggesting that the number of faculty in each category in a given year significantly predicts the number of faculty in the same category in the next year.

Based on data from a cross-sectional sample of four-year colleges and universities, Zhang and Liu (2010) suggested that a change in the number of faculty in a particular category is negatively related to its adjustment costs. When adjustment costs are low (e.g., part-time faculty), it is more difficult to predict the future employment level based on the current employment level. However, the results in Table 4 indicate that among the four types of faculty, the largest estimated coefficients are associated with part-time faculty, while the smallest estimated coefficients are associated with associate and full professors. This counter-intuitive result is due to our fixed effects models, which already account for the stable employment levels of professorial faculty. A simple correlation of faculty employment levels across years confirms this interpretation. The strengths of inter-temporal correlation coefficients become stronger moving from part-time faculty to full-time lecturers/instructors to assistant professors to associate and full professors. For example, the correlations between the (log) numbers of each faculty type in 2001-01 and 2011-12 are $0.72,0.80,0.90$, and 0.92 for part-time, full-time 
lecturers/instructors, assistant professors, and associate and full professors, respectively. ${ }^{8}$ The difference between inter-temporal correlation and fixed effects models makes perfect sense because employment of part-time faculty and full-time lecturers is related to institutional longterm strategies; thus, it is easier to predict the change in future years, given the change in a specific year. Changes in professorial faculty employment, especially at the associate and full professor levels, depend on factors such as retirement and promotion as much as new hires, and therefore changes are less predictable over time.

\section{[INSERT TABLE 4 ABOUT HERE]}

Off-diagonal coefficients also reveal some interesting patterns. Most pronounced among them is the result that changes in the number of part-time faculty are negatively related to changes in the numbers of full-time lecturers/instructors and associate/full professors, which is consistent with the notion that part-time faculty are hired to fulfill teaching needs that are unmet by full-time faculty members. The interdependence among full-time faculty members is mostly positive, except that the changes in the number of assistant professors are negatively related to changes in the number of associate and full professors. This negative relationship can be explained by the promotion of assistant professors and the employment of new assistant professors to fill vacancies left by senior professors due to retirement or moves.

The next three variables in the table are (log) average salaries for full-time lecturers/instructors, assistant professors, and associate and full professors. Estimated price elasticities are largely consistent with what economic theories would predict (i.e., negative ownprice elasticity and positive cross-price elasticity). For example, the price elasticities for all three types of full-time faculty are significant and negative, suggesting that as one type of faculty

\footnotetext{
${ }^{8}$ As one may expect, the inter-temporal correlation coefficients decrease as the length of time increases. We use the correlations between data from 2001-02 and 2011-12 to summarize the strength of inter-temporal correlation across these four types of faculty. Complete tables of correlation coefficients are available upon request.
} 
becomes more expensive over time, its employment level decreases. For full-time lecturers/instructors, a $10 \%$ increase in salary is associated with a 1.7\% decrease in employment; for assistant professors, the employment reduction is $2.6 \%$ and for associate and full professors it is $1.4 \%$. The positive cross-price elasticities between assistant professors and associate/full professors suggest that as associate/full professors become more expensive related to assistant professors, the employment level for assistant professors rises, while that for associate and full professors falls.

Results also suggest that wealthier institutions employ fewer part-time faculty and fulltime lecturers/instructors. On average, a $10 \%$ increase in current revenues is associated with a 2.3\% (not statistically significant) reduction in the number of part-time faculty and a 3.8\% reduction in the number of full-time lecturers/instructors. Estimates also show a positive income effect for assistant professors with marginally significant effects, and close to no effect on associate and full professors. These results are consistent with the view that prestige-maximizing institutions perceive a high proportion of part-time faculty and full-time teaching faculty as undesirable.

In addition, faculty employment in all categories is positively influenced by student enrollment. For example, a 10\% increase in FTE student enrollment is associated with a 3.2\% increase in the number of part-time faculty, a $2.7 \%$ increase in the number of full-time lecturers and instructors, a $1.7 \%$ increase in the number of assistant professors, and a $0.9 \%$ increase in the number of associate and full professors. While these effects are all positive and significant, institutions mainly rely on part-time faculty and full-time teaching faculty to fulfill additional teaching needs. The mixture of enrollment also matters. When total FTE enrollment is held 
constant, an increase in the proportion of part-time students is associated with an increase in the number of part-time faculty.

Finally, the three union variables do not seem to affect faculty employment of different types. In addition to the possibility that the effects of unions are unclear, as we discussed earlier in the paper, the small number of institutions that changed their union statuses during the sample period may also be a factor. For example, during the years included in our panel data models, only about 2 dozen institutions had changed their statuses on at least one of the three union variables, accounting for less than $2 \%$ of institutions included in our sample. As a result, most estimates are not statistically significant. The only two statistically significant estimates are the effects of part-time faculty unions on the employment levels of part-time faculty and full-time teaching faculty. Results suggest that part-time faculty unions support the expansion of part-time faculty, which limits the expansion of full-time teaching faculty.

To examine whether faculty employment patterns vary across types of institutions, we ran separate analyses for doctoral/research institutions, master’s institutions, and bachelor's institutions. Results are reported in Appendix Tables A-C. This set of tables reveals qualitatively similar patterns across the three types of institutions. For example, with regard to the relationship between the change in employment levels in a given year and the change in the next year, the largest estimated coefficients are associated with part-time faculty across all three types of institutions, while the lowest estimated coefficients are associated with associate and full professors at bachelor's and master's institutions, and with assistant professors at doctoral/research institutions. Own-price elasticities within each faculty type are consistently negative across all three types of institutions, while cross-price elasticities are generally positive, especially between assistant professors and associate/full professors. 
Across all three types of institutions, our estimates indicate negative revenue effects for part-time faculty and full-time lecturers/instructors and positive effects for assistant professors. An increase in student enrollment is associated with an increase in faculty employment in all categories overall. The largest impact, however, differs across institutions. Among doctoral/research institutions, the numbers of full-time lecturers/instructors and assistant professors increased the most, while among master's and bachelor's institutions, the numbers of part-time faculty and full-time lecturers and instructors increased the most. The employment level of part-time faculty is positively related to the proportion of part-time student enrollment; however, estimates and significance levels vary across types of institutions.

In the next step of the analysis, we had hoped to use similar dynamic panel data models to examine determinants of the increasing employment of non-tenure track full-time professorial faculty; however, this approach was not possible because IPEDS data for one of the key elements in Eq. 1, the average salary for each type of faculty, are not differentiated by tenure track status. Given this major limitation, we chose to take a cross-sectional approach to examine variations in the prevalence of non-tenure-track faculty across institutions. Although this approach does not generate strong causal inferences like the dynamic panel data approach, it nonetheless sheds light on the factors that may be related to the increasing usage of non-tenure track faculty. In Table 5, we present results from our two models, with full-time lecturers/instructors included (the first model) and excluded (the second model). These cross-sectional models include several additional institutional characteristics that are constant over time (e.g., whether an institution has a medical school, private vs. public, and Carnegie classification). Results presented here are estimated using pooled data with year dummies. Year-by-year results are very similar (only with smaller $t$-values) to those discussed previously in this section. 


\section{[INSERT TABLE 5 ABOUT HERE]}

The first model includes all full-time faculty (i.e., professors and full-time lecturers and instructors), while the second model incudes only faculty with professorial ranks. These two

models yield similar results. For example, institutional wealth is negatively related to the share of full-time faculty who were not on tenure tracks. In other words, wealthier institutions employed a higher proportion of tenured or tenure-track faculty. Larger institutions, as measured by FTE student enrollment employed fewer non-tenure track faculty. This is consistent with the notion that large institutions are better able to reassign faculty to different positions in the event of workload changes; further, large institutions, especially doctoral/research institutions, can hire graduate students to teach undergraduate courses, thus reducing the need for part-time faculty and full-time non-tenure track faculty. Institutions with a large proportion of part-time students employed more non-tenure track faculty.

In additional analyses not reported in this table, we add the share of doctoral students to test whether institutions with more doctoral students employ fewer full-time non-tenure track faculty. Because the vast majority of master's and bachelor's institutions have no doctoral students, this additional model is estimated for research and doctoral institutions only. Results confirm a negative association between the share of doctoral students and the share of full-time non-tenure track faculty; however, a higher share of doctoral students does not necessarily decrease the share of non-tenure track faculty among full-time professorial faculty. In other words, institutions use graduate students to substitute full-time lecturers and instructors, but not full-time faculty with professorial ranks.

Institutional characteristics are also related to the employment of full-time non-tenure track faculty. Institutions with medical schools employed a much higher proportion of non- 
tenure track faculty than institutions without medical schools. Medical schools have a tradition of hiring clinical and research faculty whose contracts are tied to the durations of external grants. Private institutions employed more non-tenure track faculty than their public counterparts, indicating that private institutions may have more flexibility in faculty employment, and thus be more likely to pursue cost savings and economic efficiency. The share of non-tenure track fulltime faculty was higher at doctoral/research institutions than at master's and bachelor's institutions. This is probably due to the emphasis on research for tenure-track faculty at doctoral/research institutions. In addition, because of their higher compensation levels, academic appointments at doctoral/research institutions (even non-tenure track appointments) are more attractive than similar appointments at master's and bachelor's institutions.

Finally, there are significant variations across institutions in the share of full-time nontenure track faculty by union status. As expected, at institutions with full-time tenure track faculty unions, full-time non-tenure track employees comprised a lower share of the overall faculty, because the goal of a full-time tenure track faculty union is to increase salaries and protect the job security of these faculty members. The positive association between the presence of a full-time non-tenure track union and the proportion of faculty comprised of full-time nontenure track employees is a bit surprising, because the presence of these unions may discourage institutions from hiring more full-time non-tenure track faculty. However, the presence of these unions may improve working conditions (e.g., salaries and benefits, job security) of full-time non-tenure track faculty, thus making the institutions more attractive. This positive association could also be due to reverse causation (i.e., that when a large share of faculty are full-time nontenure track employees, non-tenure track faculty unions are more likely to be created). Similarly, the negative association between the presence of part-time faculty unions and the share of full- 
time non-tenure track faculty could also be due to reverse causation (i.e., when there are many part-time and few full-time non-tenure track faculty, part-time faculty unions are more likely to be created). Again, these observations are based on cross-institutional variations. When we used dynamic panel data models without controlling for salaries, all union variables became statistically insignificant.

\section{Concluding Remarks}

In this paper, we used panel data models to examine variations and changes in faculty employment at four-year colleges and universities in the United States in recent decades. Our study produced several findings. First, the share of total faculty comprised of part-time employees has continued to grow during the last two decades or so, from about $30 \%$ in 1993 to about 38\% of total faculty in recent years. The proportion of full-time lecturers and instructors, however, has been relatively stable, hovering around $11 \%$ of the total faculty during the study period. One significant change is the growing share of non-tenure track faculty among full-time faculty, especially among the professorial ranks. Roughly 1 out of every 5 professors is not eligible for tenure; for assistant professors, that ratio grows to 1 out of every 3 . The significant increase in the proportion of non-tenure track professorial faculty is the most recent trend signaling the slow, continuing erosion of the tenure system in U.S. higher education since the 1970s.

Second, our dynamic panel data models indicate that employment levels of different faculty types respond to a variety of economic and institutional factors. Negative own-price elasticities within faculty types and positive cross-price elasticities suggest that everything else being equal, higher education institutions employ faculty whose salaries and benefits are 
relatively less expensive. The large gap in compensation between part-time faculty and full-time faculty has certainly contributed to the increasing use of part-time faculty over time. In addition, although prestige-maximizing institutions hire more professorial faculty than part-time faculty and full-time teaching faculty, the slowly deteriorating financial situations at most colleges and universities have led to an over-reliance on contingent academic workers. The growing unionization of these contingent faculty members will probably slow down the process a bit; however, our empirical models were not able to detect these effects because very few transitions in union status occurred during the study period.

Third, a cross-sectional comparison of the share of full-time non-tenure track faculty reveals significant variations across institutions. Full-time non-tenure track faculty are more prevalent at private institutions, institutions with medical schools, and doctoral/research institutions. In addition, large and wealthy institutions hire fewer full-time non-tenure track faculty members, as do institutions with fewer part-time students. Again, the effect of union status is not clear and may suffer from reverse causation in cross-sectional models.

Given the precarious fiscal environment encountered by many colleges and universities and the current over-supply of doctoral degree holders in many academic fields, it is almost certain that the use of contingent faculty—part-time faculty, full-time lecturers and instructors, and non-tenure track professors—will continue to grow. The question is whether we have achieved a new equilibrium of faculty composition (Monk, Dooris, \& Erickson 2009) or are on a slippery slope that will eventually lead to the dissolution of tenure as we know it. Faculty unionization is an important factor to consider when contemplating this question. On one hand, the unionization of contingent faculty could reduce incentives for institutions to hire more such employees. At the University of Cincinnati, for example, full-time non-tenure track faculty 
members enjoy the same benefits as tenure-track faculty members, including sabbaticals, health and life insurance, and retirement benefits. On the other hand, (the possibility of) unionization of full-time tenure track faculty could support the preservation of tenure. The recent union case at Pacific Lutheran University challenges the assumption that upheld the Yeshiva decision: fulltime tenure-track faculty members at private institutions are automatically managerial employees. This could motivate private institutions to reevaluate their vulnerability to union organizing among tenure-track faculty and renegotiate the relationship between administration and faculty. Among all these trends, perhaps the most relevant question related to contingent faculty employment is its impact on institutional performance, including, for example, student learning and research activities. The jury is still out on the impact of contingent faculty on student learning and college outcomes. While some studies have shown a negative impact of contingent faculty on student learning and graduation (Ehrenberg \& Zhang 2005; Umbach 2007), others have shown a positive impact of adjunct faculty on follow-on course interest and performance (Bettinger \& Long 2010; Figlio, Schapiro, \& Soter 2013). Carrell and West (2010) suggested that while adjunct faculty may promote students' interest in a subject through higher grades, they perform significantly worse in subsequent courses in the subject. Without substantial evidence on the adverse effect of this growing practice of contingent employment, the trend is likely to continue. 


\section{References:}

Anderson, E. L. (2002). The new professoriate: Characteristics, contributions and compensation. Washington DC: American Council on Education.

Arellano, M., and Bond, S. (1991). Some tests of specification for panel data: Monte Carlo evidence and an application to employment equations. Review of Economic Studies, 58(2), 277-297.

Bettinger, E. P., and Long, B. T. (2010). Does cheaper mean better? The impact of using adjunct instructors on student outcomes. The Review of Economics and Statistics, 92(3), 598-613.

Carnegie Foundation for the Advancement of Teaching (2011). The Carnegie classification of institutions of higher education, 2010 edition. Menlo Park, CA: Author.

Carrell, S. E., and West, J. E. (2010). Does professor quality matter? Evidence from random assignment of students to professors. Journal of Political Economy, 118(3), 409-432.

Cheslock, J. J., and Callie, T. M. (2015). Changing salary structure and faculty composition within business schools: Differences across sectors and state funding levels. Economics of Education Review, 49, 42-54.

Conley, V. M., and Leslie, D. W. (2002). Part-time instructional faculty and staff: Who they are, what they do, and what they think. Washington, DC: U.S. Department of Education.

Ehrenberg, R. G., and Zhang, L. (2005). Do tenured and tenure-track faculty matter? Journal of Human Resources, 40(3), 647-659.

Figlio, D. N., Schapiro, M. O., and Soter, K. B. (2013). Are tenure track professors better teachers? (No. W19406). Cambridge, MA: National Bureau of Economic Research.

Gappa, J. M., and Leslie, D. (1993). The invisible faculty: Improving the status of part-timers in higher education. San Francisco: Jossey-Bass. 
Hedrick, D. W., Henson, S. E., Krieg, J. M., and Wassell, C. S. (2011). Is there really a faculty union salary premium? Industrial \& Labor Relations Review, 64(3), 558-575.

Johnson, W. R., and Turner, S. (2009). Faculty without students: Resource allocation in higher education. The Journal of Economic Perspectives, 32(2), 169-189.

Kezar, A., and Sam, C. (2010). Special issue: Understanding the new majority of non-tenuretrack faculty in higher education-Demographics, experiences, and plans of action. ASHE Higher Education Report, 36(4), 1-133.

Liu, X., and Zhang, L. (2013). Flexibility at the core: What determines employment of part-time faculty in academia. Industrial Relations, 68(2), 312-339.

Liu, X., and Zhang, L. (2015). Examining the relationship among part-time work arrangement, job satisfaction, and work effort: A study of U.S. college faculty. Advances in Industrial and Labor Relations, 21, 87-117.

Maynard, D. C., and Joseph, T. A. (2008). Are all part-time faculty underemployed? The influence of faculty status preference on satisfaction and commitment. Higher Education, 55(2), 139-154.

Monk, D. H., Dooris, M. J., and Erickson, R. A. (2009). In search of a new equilibrium: Economic aspects of higher education's changing faculty composition. Education Finance and Policy, 4(3), 300-318.

Monks, J. (2009). Who are the part-time faculty? Academe, 95(4), 33-37.

Rhoades, G. (1998). Managed professionals: Unionized faculty and restructuring academic labor. Albany, NY: SUNY Press.

Roemer, R. E., and Schnitz, J. E. (1982). Academic employment as day labor: The dual labor market in higher education. The Journal of Higher Education, 53(5), 514-531. 
Rosenblum, G., and Rosenblum, B. R. (1990). Segmented labor markets in institutions of higher learning. Sociology of Education, 63(3), 151-164.

Umbach, P. D. (2007). How effective are they? Exploring the impact of contingent faculty on undergraduate education. The Review of Higher Education, 30(2), 91-123.

Zhang, L., and Liu, X. (2010). Faculty employment at 4-year colleges and universities. Economics of Education Review, 29(4), 543-552.

Zhang, L., and Ehrenberg, R. G. (2010). Faculty employment and R\&D expenditures at research universities. Economics of Education Review, 29(3), 329-337. 
Figure 1: Proportions of Part-time Faculty, Full-time Instructors and Lecturers, and Full-time Professorial Faculty, 1993-2013

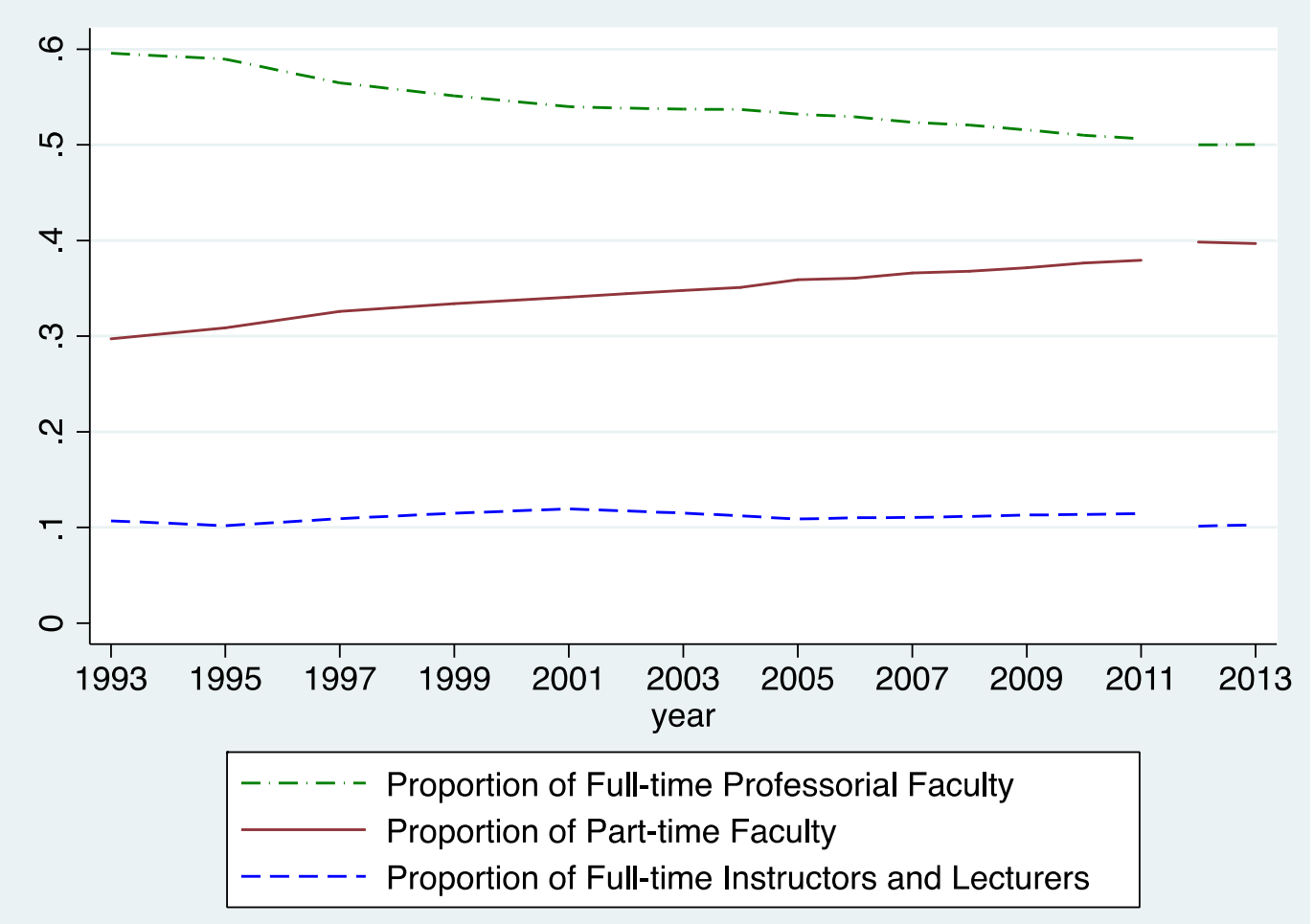

Note: The break between 2011 and 2012 is due to the change in the definition of instructional faculty in the Fall Staff Survey. 
Figure 2: Proportions of Non-tenure Track Full-time Faculty, by Rank, 1993-2013

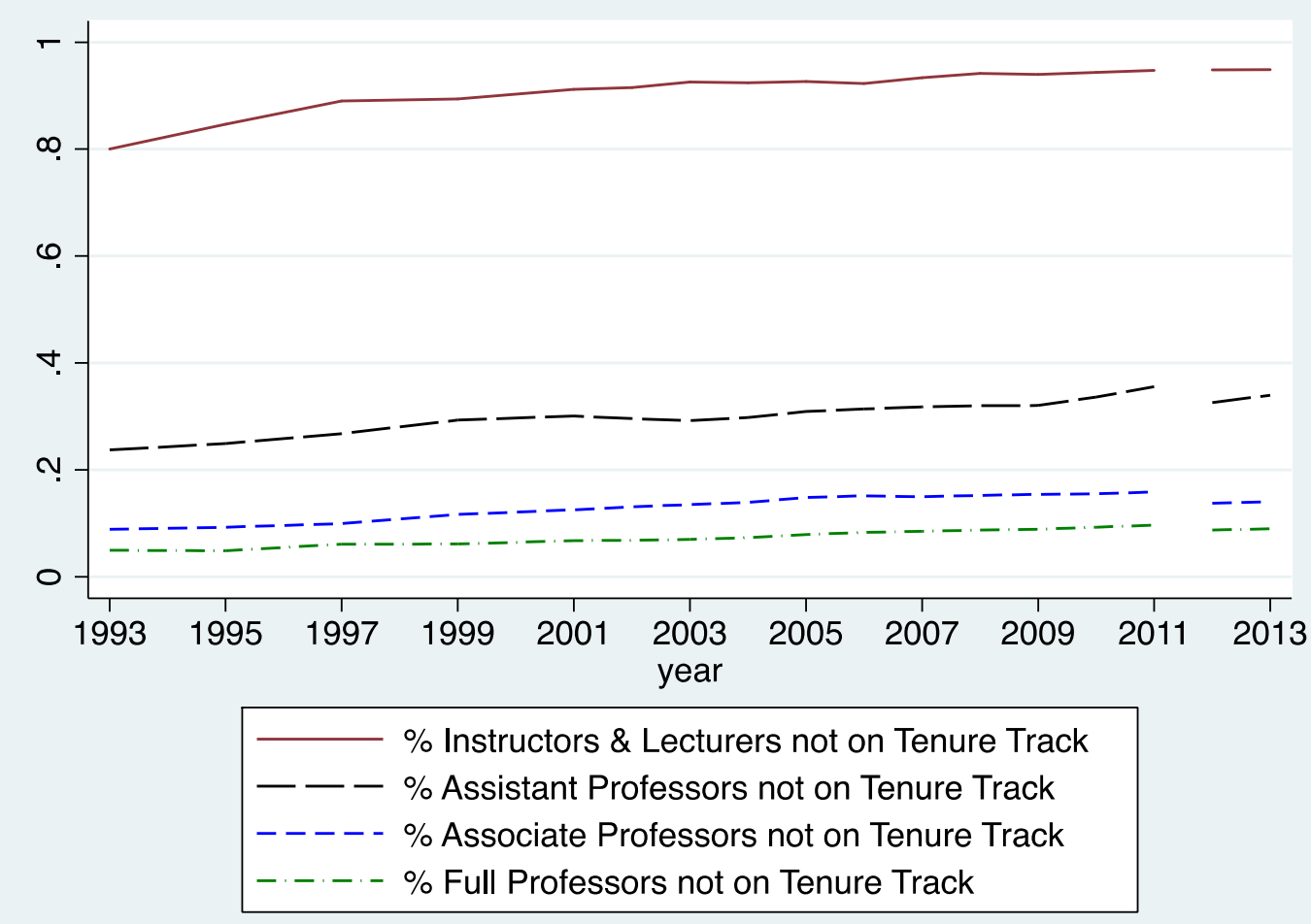

Note: The break between 2011 and 2012 is due to the change in the definition of instructional faculty in the Fall Staff Survey. 
Table 1: Variables and Data Sources

\begin{tabular}{ll}
\hline Variable & IPEDS Surveys \\
\hline Number of part-time faculty & Fall Staff \\
Number of full-time lecturers and Instructors & Fall Staff \\
Number of professorial faculty & Fall Staff \\
Number of assistant professors & Fall Staff \\
Number of associate and full professors & Fall Staff \\
Average salary of professorial faculty & Faculty Salary \\
Average salary of assistant professors & Faculty Salary \\
Average salary of associate and full professors & Faculty Salary \\
Average salary of full-time teaching faculty & Faculty Salary \\
Institutional revenues & Finance \\
FTE enrollment & Enrollment \\
Proportion of part-time students & Enrollment \\
Private institutions & Institutional Characteristics \\
Carnegie classification & Institutional Characteristics \\
Medical school & Institutional Characteristics \\
Full-time tenure-track union & NCSCBHEP \\
Full-time non-tenure track union & NCSCBHEP \\
Part-time non-tenure track union & NCSCBHEP
\end{tabular}

NCSCBHEP: National Center for the Study of Collective Bargaining in Higher Education and the Professions 
Table 2: Faculty Employment at Four-Year Colleges and Universities, by Control and Institution Type, 1993-2011

\begin{tabular}{|c|c|c|c|c|c|c|c|}
\hline \multirow[b]{2}{*}{ Public institutions } & \multirow[b]{2}{*}{$\begin{array}{c}\text { No. of } \\
\text { Institutions }\end{array}$} & \multicolumn{3}{|c|}{1993} & \multicolumn{3}{|c|}{2011} \\
\hline & & $\begin{array}{c}\text { Part-time } \\
\text { faculty }\end{array}$ & $\begin{array}{l}\text { Full-time } \\
\text { lecturers }\end{array}$ & $\begin{array}{c}\text { Full-time } \\
\text { professors }\end{array}$ & $\begin{array}{c}\text { Part-time } \\
\text { faculty }\end{array}$ & $\begin{array}{l}\text { Full-time } \\
\text { lecturers }\end{array}$ & $\begin{array}{l}\text { Full-time } \\
\text { professors }\end{array}$ \\
\hline Doctoral/research & 160 & $19.4(12.6)$ & $12.9(9.0)$ & $67.8(14.0)$ & $25.8(11.7)$ & $14.5(8.1)$ & $59.7(12.2)$ \\
\hline Master’s & 242 & 30.4 (18.5) & $7.6(10.5)$ & $62.0(18.7)$ & $42.0(15.4)$ & $10.5(8.2)$ & $47.6(13.0)$ \\
\hline Bachelor's & 92 & 36.8 (19.7) & $13.3(14.1)$ & $49.9(22.9)$ & 47.7 (17.8) & $10.9(9.4)$ & $41.3(17.7)$ \\
\hline Sub-total & 494 & $23.5(17.6)$ & $11.3(10.8)$ & $65.2(18.7)$ & $32.0(15.8)$ & $13.0(8.5)$ & $54.9(14.4)$ \\
\hline
\end{tabular}

Private institutions

\begin{tabular}{lllrrrrr}
\hline Doctoral/research & 106 & $31.6(23.1)$ & $12.7(14.4)$ & $55.6(23.7)$ & $35.4(20.9)$ & $13.5(10.7)$ & $51.1(17.8)$ \\
Master's & 363 & $51.8(22.5)$ & $6.4(10.8)$ & $41.8(22.4)$ & $59.5(20.2)$ & $5.4(8.0)$ & $35.1(18.7)$ \\
Bachelor's & 500 & $33.7(19.4)$ & $9.3(14.1)$ & $57.0(22.9)$ & $40.3(20.7)$ & $8.5(12.5)$ & $51.2(22.7)$ \\
Sub-total & 969 & $38.7(21.9)$ & $9.8(14.4)$ & $51.4(24.0)$ & $45.3(21.8)$ & $9.5(10.9)$ & $45.3(21.6)$ \\
\hline
\end{tabular}

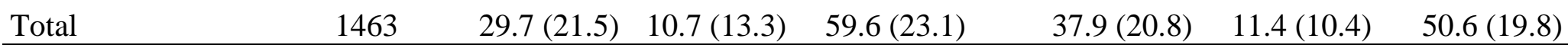

Note: Doctoral/research institutions include institutions that awarded at least 20 research doctoral degrees during 2010 (excluding doctoral-level degrees that qualify recipients for entry into professional practice, such as the JD, MD, PharmD, DPT, etc.). Master's institutions include institutions that awarded at least 50 master's degrees and fewer than 20 doctoral degrees during 2010. Bachelor's institutions include institutions where baccalaureate degrees represent at least $10 \%$ of all undergraduate degrees and where fewer than 50 master's degrees or 20 doctoral degrees were awarded during the update year. 
Table 3: Proportion of Non-tenure Track Full-time Faculty by Rank at Four-Year Colleges and Universities, by Control and Institution Type, 1993-2011

\begin{tabular}{|c|c|c|c|c|c|c|c|c|c|c|}
\hline \multirow[b]{2}{*}{ Public institutions } & \multicolumn{5}{|c|}{1993} & \multicolumn{5}{|c|}{2011} \\
\hline & All & $\mathrm{L} / \mathrm{I}$ & Asst. & Assoc. & Full & All & $\mathrm{L} / \mathrm{I}$ & Asst. & Assoc. & Full \\
\hline Doctoral/research & 23.2 & 89.7 & 23.6 & 7.3 & 3.5 & 35.5 & 97.7 & 39.2 & 16.0 & 8.3 \\
\hline Master’s & 13.2 & 75.8 & 11.5 & 3.3 & 2.7 & 22.1 & 94.1 & 14.2 & 2.6 & 2.0 \\
\hline Bachelor's & 19.5 & 55.8 & 18.4 & 5.3 & 4.8 & 25.3 & 72.3 & 20.2 & 8.3 & 7.4 \\
\hline Subtotal & 20.3 & 84.9 & 19.8 & 6.1 & 3.3 & 31.5 & 95.7 & 31.2 & 12.0 & 6.7 \\
\hline
\end{tabular}

Private institutions

\begin{tabular}{lcccccccccc} 
Doctoral/research & 28.7 & 74.8 & 34.0 & 15.6 & 7.2 & 41.5 & 96.4 & 44.1 & 24.9 & 14.1 \\
Master's & 25.3 & 75.9 & 27.7 & 13.1 & 9.7 & 37.0 & 92.6 & 42.7 & 22.1 & 17.1 \\
Bachelor's & 22.3 & 60.8 & 26.0 & 12.5 & 9.5 & 30.8 & 82.8 & 35.9 & 16.8 & 12.4 \\
Subtotal & 26.2 & 72.0 & 30.1 & 14.0 & 8.4 & 37.8 & 93.1 & 41.7 & 22.0 & 14.4 \\
\hline & & & & & & & & & & \\
Total & 22.4 & 80.0 & 23.7 & 8.9 & 5.0 & 34.0 & 94.7 & 35.6 & 15.9 & 9.7 \\
\hline
\end{tabular}

Note: L/I = Lecturer/Instructor; Asst. = Assistant Professor; Assoc. = Associate Professor; Full = Full Professor 
Table 4: Dynamic Panel Estimation for Employment Levels of Faculty Types with Cross Lag Terms, 2001-2011 ( $N=14,218)$

\begin{tabular}{|c|c|c|c|c|}
\hline & & Full-time & & Associate \& \\
\hline & $\begin{array}{l}\text { Part-time } \\
\text { faculty }\end{array}$ & $\begin{array}{l}\text { lecturers \& } \\
\text { instructors }\end{array}$ & $\begin{array}{l}\text { Assistant } \\
\text { professors }\end{array}$ & $\begin{array}{c}\text { full } \\
\text { professors }\end{array}$ \\
\hline Log number of part-time faculty, $t-1$ & $.705^{* * *}$ & -.0118 & $.0116^{* *}$ & $.00393^{*}$ \\
\hline & $(49.35)$ & $(-1.18)$ & $(2.71)$ & $(1.97)$ \\
\hline Log number of full-time lecturers, $t-1$ & $-.0379^{* * *}$ & $.655^{* * *}$ & $.0315^{* * *}$ & $.0148^{* * *}$ \\
\hline & $(-3.44)$ & $(30.62)$ & (6.98) & $(6.95)$ \\
\hline Log number of assistant professors, $t-1$ & .0410 & $.144^{* * *}$ & $.565^{* * *}$ & $.0149^{* * *}$ \\
\hline & $(1.80)$ & $(6.65)$ & $(32.46)$ & (3.39) \\
\hline Log number of associate \& full professors, $t-1$ & $-.103^{* *}$ & $0.290^{* * *}$ & $-.0886^{* * *}$ & $.224^{* * *}$ \\
\hline & $(-3.02)$ & $(8.78)$ & $(-6.40)$ & $(17.09)$ \\
\hline Log avg. salary of lecturers & .0559 & $-.169^{* * *}$ & -.00954 & -.0137 \\
\hline & $(1.24)$ & $(-3.96)$ & $(-0.52)$ & $(-1.61)$ \\
\hline Log avg. salary of assistant professors & -.0457 & .107 & $-.255^{* * *}$ & $.0556^{* *}$ \\
\hline & $(-0.47)$ & $(1.17)$ & $(-6.53)$ & $(3.04)$ \\
\hline Log avg. salary of associate \& full professors & .0175 & .0811 & $.236^{* * *}$ & $-.139^{* * *}$ \\
\hline & $(0.16)$ & $(0.80)$ & $(5.47)$ & $(-6.91)$ \\
\hline Log revenue & -.0234 & $-.0378^{*}$ & .0131 & -.00052 \\
\hline & $(-1.22)$ & $(-2.08)$ & (1.68) & $(-0.14)$ \\
\hline Log number of FTE students & $.315^{* * *}$ & $.274^{* * *}$ & $.168^{* * *}$ & $.0891^{* * *}$ \\
\hline & $(6.05)$ & (5.59) & $(7.98)$ & $(9.08)$ \\
\hline Proportion of part-time students & $.0464^{*}$ & -.0288 & -.0133 & .00297 \\
\hline & $(2.28)$ & $(-1.49)$ & $(-1.61)$ & $(0.77)$ \\
\hline Full-time tenure-track union, $t$-1 & -.0473 & -0.349 & .0146 & -.0197 \\
\hline & $(-0.19)$ & $(-1.47)$ & $(0.14)$ & $(-0.42)$ \\
\hline Full-time non-tenure track union, $t-1$ & -.130 & 0.139 & -.0184 & .0112 \\
\hline & $(-0.55)$ & $(0.62)$ & $(-0.19)$ & $(0.25)$ \\
\hline Part-time non-tenure track union, $t$-1 & $.266^{*}$ & $-.252^{*}$ & -.0226 & -.0350 \\
\hline & $(1.98)$ & $(-2.00)$ & $(-0.42)$ & $(-1.39)$ \\
\hline
\end{tabular}


Table 5: Cross-Sectional Model for the Share of Full-time NTT Faculty, 2001-2011

\begin{tabular}{lcc}
\hline & $\begin{array}{c}\text { All full-time } \\
\text { faculty }\end{array}$ & $\begin{array}{c}\text { Professorial } \\
\text { faculty only }\end{array}$ \\
\hline Log revenue per FTE student & $-.0721^{* * *}$ & $-.0691^{* * *}$ \\
Log number of FTE students & $(-15.10)$ & $(-13.66)$ \\
& $-.0156^{*}$ & $-.0427^{* * *}$ \\
Proportion of part-time students & $(-2.40)^{* * *}$ & $(-6.11)^{* * *}$ \\
& $.0337^{* * *}$ & $.0326^{* * *}$ \\
Has medical school & $(14.79)^{* *}$ & $(13.29)$ \\
& $.172^{* * *}$ & $.221^{* * *}$ \\
Private institutions & $(16.54)$ & $(20.40)$ \\
& $.102^{* * *}$ & $.165^{* * *}$ \\
Research/doctoral institutions & $(16.40)$ & $(25.15)$ \\
& $.0303^{* *}$ & $.0678^{* * *}$ \\
Master's institutions & $(3.12)$ & $(6.53)$ \\
Full-time tenure-track union & -.00183 & .0130 \\
& $(-0.30)^{* * *}$ & $(1.96)$ \\
Full-time non-tenure track union & $-.0436^{* * *}$ & $-.0270^{*}$ \\
& $(-4.18)^{* * *}$ & $(-2.48)^{* *}$ \\
Part-time non-tenure track union & $.0607^{* * *}$ & $.0507^{* * *}$ \\
& $(4.75)^{* * *}$ & $(3.80)^{*}$ \\
\hline$N$ & $-.0609^{* * *}$ & $-.0274^{*}$ \\
\hline
\end{tabular}

Note: Year fixed effects are also included in all models; t-values in parentheses; ${ }^{*} p<0.05,{ }^{* *} p<$ $0.01,{ }^{* * *} p<0.001$ 
Appendix Table A: Dynamic Panel Estimation for Employment Levels of Different Types of Faculty at Research and Doctoral Institutions, 2001-2011 $(N=2,716)$

\begin{tabular}{|c|c|c|c|c|}
\hline & $\begin{array}{l}\text { Part-time } \\
\text { faculty }\end{array}$ & $\begin{array}{c}\text { Full-time } \\
\text { lecturers \& } \\
\text { instructors }\end{array}$ & $\begin{array}{l}\text { Assistant } \\
\text { professors }\end{array}$ & $\begin{array}{l}\text { Associate \& } \\
\text { full professors }\end{array}$ \\
\hline Log number of part-time faculty, $t-1$ & $.737^{* * *}$ & -.0101 & .00783 & $.00839^{*}$ \\
\hline & $(31.11)$ & $(-0.46)$ & $(1.00)$ & $(2.09)$ \\
\hline Log number of full-time lecturers, $t-1$ & $-.0473^{*}$ & $.581^{* * *}$ & $.0264^{* * *}$ & .0000446 \\
\hline & $(-2.21)$ & $(18.24)$ & $(3.34)$ & $(0.01)$ \\
\hline Log number of assistant professors, $t-1$ & $.398^{* * *}$ & .0468 & $.119^{* * *}$ & $-.0306^{*}$ \\
\hline & $(6.54)$ & $(0.79)$ & $(3.56)$ & $(-2.43)$ \\
\hline Log number of assoc. \& full professors, $t-1$ & $-.639^{* * *}$ & .127 & $.163^{* * *}$ & $.595^{* * *}$ \\
\hline & $(-5.14)$ & $(1.06)$ & $(3.95)$ & $(12.43)$ \\
\hline Log avg. salary of lecturers & -.0430 & -.0967 & .00479 & -.0132 \\
\hline & $(-0.56)$ & $(-1.31)$ & $(0.17)$ & $(-0.96)$ \\
\hline Log avg. salary of assistant professors & $-.938^{* * *}$ & -.276 & $-.342^{* * *}$ & .0182 \\
\hline & $(-4.62)$ & $(-1.13)$ & $(-3.75)$ & $(0.40)$ \\
\hline Log avg. salary of assoc. \& full professors & .266 & .469 & 0.152 & $-.159^{* *}$ \\
\hline & $(1.02)$ & $(1.52)$ & $(1.33)$ & $(-2.86)$ \\
\hline Log revenue & -.0227 & -.0250 & .0117 & -.000105 \\
\hline & $(-0.51)$ & $(-0.59)$ & $(0.74)$ & $(-0.01)$ \\
\hline Log number of FTE students & -.0266 & $.294^{*}$ & $.314^{* * *}$ & $.0768^{* *}$ \\
\hline & $(-0.19)$ & $(2.21)$ & $(6.51)$ & $(3.05)$ \\
\hline Proportion of part-time students & .120 & -.0526 & $-.0670^{* *}$ & .0248 \\
\hline & $(1.66)$ & $(-0.76)$ & $(-2.59)$ & $(1.87)$ \\
\hline Full-time tenure-track union, $t-1$ & -.0377 & -.235 & .0351 & -.0329 \\
\hline & $(-0.15)$ & $(-0.94)$ & $(0.37)$ & $(-0.70)$ \\
\hline Full-time non-tenure track union, $t-1$ & -.0425 & .140 & -.114 & -.0113 \\
\hline & $(-0.16)$ & $(0.57)$ & $(-1.21)$ & $(-0.24)$ \\
\hline Part-time non-tenure track union, $t-1$ & $.308^{*}$ & -.00960 & -.0641 & -.0173 \\
\hline & $(2.15)$ & $(-0.07)$ & $(-1.24)$ & $(-0.68)$ \\
\hline
\end{tabular}


Appendix Table B: Dynamic Panel Estimation for Employment Levels of Different Types of Faculty at Master's Institutions, 2001-2011 $(N=6,108)$

\begin{tabular}{|c|c|c|c|c|}
\hline & $\begin{array}{l}\text { Part-time } \\
\text { faculty }\end{array}$ & $\begin{array}{l}\text { Full-time } \\
\text { lecturers } \\
\& \\
\text { instructors }\end{array}$ & $\begin{array}{c}\text { Assistant } \\
\text { professors }\end{array}$ & $\begin{array}{c}\text { Associate \& } \\
\text { full } \\
\text { professors }\end{array}$ \\
\hline Log number of part-time faculty, $t-1$ & $.701^{* * * *}$ & .0104 & .00261 & $.00680^{*}$ \\
\hline & $(38.38)$ & $(0.73)$ & $(0.50)$ & $(2.52)$ \\
\hline Log number of full-time lecturers, $t-1$ & $-.0611^{* *}$ & $.680^{* * *}$ & $.0391^{* * *}$ & $.0162^{* * *}$ \\
\hline & $(-3.18)$ & $(21.83)$ & $(6.36)$ & $(5.08)$ \\
\hline Log number of assistant professors, $t-1$ & .0133 & $.134^{* * *}$ & $.584^{* * *}$ & .0116 \\
\hline & $(0.33)$ & $(4.02)$ & $(32.13)$ & $(1.84)$ \\
\hline Log number of assoc. \& full professors, $t-1$ & -.105 & $.304^{* * *}$ & $-.0950^{* * *}$ & $.287^{* * *}$ \\
\hline & $(-1.87)$ & $(6.30)$ & $(-5.48)$ & $(22.87)$ \\
\hline Log avg. salary of lecturers & .0149 & $-.161^{*}$ & $-.0644^{*}$ & $.0289^{*}$ \\
\hline & $(0.19)$ & $(-2.37)$ & $(-2.55)$ & $(2.22)$ \\
\hline Log avg. salary of assistant professors & -.0204 & .242 & $-.231^{* * *}$ & -.0187 \\
\hline & $(-0.12)$ & $(1.62)$ & $(-4.18)$ & $(-0.65)$ \\
\hline Log avg. salary of assoc. \& full professors & -.133 & .135 & $.561^{* * *}$ & $-.149^{* * *}$ \\
\hline & $(-0.63)$ & $(0.76)$ & $(8.51)$ & $(-4.34)$ \\
\hline Log revenue & -.0789 & $-.122^{*}$ & .0140 & $.0212^{*}$ \\
\hline & $(-1.32)$ & $(-2.42)$ & $(0.75)$ & $(2.18)$ \\
\hline Log number of FTE students & $.505^{* * *}$ & .136 & $.129^{* * *}$ & .0219 \\
\hline & $(5.46)$ & $(1.74)$ & $(4.46)$ & $(1.45)$ \\
\hline Proportion of part-time students & .0629 & .0495 & -.0188 & .0129 \\
\hline & (1.43) & (1.33) & $(-1.35)$ & $(1.81)$ \\
\hline Full-time tenure-track union, $t-1$ & -.120 & $-.862^{*}$ & .0360 & .0539 \\
\hline & $(-0.25)$ & $(-2.09)$ & $(0.23)$ & $(0.67)$ \\
\hline Full-time non-tenure track union, $t-1$ & -.359 & .691 & -.0791 & -.0333 \\
\hline & $(-0.83)$ & $(1.92)$ & $(-0.58)$ & $(-0.47)$ \\
\hline Part-time non-tenure track union, $t$-1 & .336 & $-.742^{* * *}$ & .0510 & .00377 \\
\hline & $(1.26)$ & $(-3.37)$ & $(0.60)$ & $(0.09)$ \\
\hline
\end{tabular}

Note: Year fixed effects are also included in all models; t-values in parentheses; ${ }^{*} p<0.05,{ }^{* *} p<$ $0.01,{ }^{* * *} p<0.001$ 
Appendix Table C: Dynamic Panel Estimation for Employment Levels of Different Types of Faculty at Bachelor's Institutions, 2001-2011

\begin{tabular}{lcccc}
\hline & $\begin{array}{c}\text { Part-time } \\
\text { faculty }\end{array}$ & $\begin{array}{c}\text { Full-time } \\
\text { lecturers \& } \\
\text { instructors }\end{array}$ & $\begin{array}{c}\text { Assistant } \\
\text { professors }\end{array}$ & $\begin{array}{c}\text { Associate \& } \\
\text { full professors }\end{array}$ \\
\hline Log number of part-time faculty, $t-1$ & $.715^{* * *}$ & -.0316 & $.0183^{*}$ & -.00226 \\
& $(32.36)$ & $(-1.79)^{* * *}$ & $(2.30)^{* * *}$ & $(-0.57)^{* * *}$ \\
Log number of full-time lecturers, $t-1$ & -.0223 & $0.647^{* * *}$ & $.0266^{* * *}$ & $.0208^{* * *}$ \\
& $(-1.39)$ & $(22.22)^{* * *}$ & $(3.41)^{* * *}$ & $(5.32)$ \\
Log number of assistant professors, $t-1$ & -.000875 & $0.153^{* * *}$ & $.458^{* * *}$ & .00665 \\
& $(-0.03)$ & $(4.57)^{* * *}$ & $(18.51)$ & $(0.91)^{* * *}$ \\
Log number of assoc. \& full professors, $t-1$ & $-.0920^{*}$ & $0.282^{* * *}$ & $-.0467^{*}$ & $.267^{* * *}$ \\
& $(-2.01)$ & $(5.63)^{* * *}$ & $(-2.19)$ & $(12.98)^{* *}$ \\
Log avg. salary of lecturers & $.155^{*}$ & $-0.249^{* *}$ & -.00421 & $-.0435^{* *}$ \\
& $(2.18)$ & $(-3.30)$ & $(-0.12)$ & $(-2.59)^{* * *}$ \\
Log avg. salary of assistant professors & .171 & 0.154 & $-.228^{* * *}$ & $.109^{* * *}$ \\
& $(1.34)$ & $(1.14)$ & $(-3.75)$ & $(3.60)^{* * *}$ \\
Log avg. salary of assoc. \& full professors & -.133 & 0.0421 & $.133^{*}$ & $-.141^{* * *}$ \\
& $(-1.01)$ & $(0.30)$ & $(2.11)$ & $(-4.51)$ \\
Log revenue & -.0169 & -0.0305 & .0113 & -.00596 \\
Log number of FTE students & $(-0.76)$ & $(-1.29)^{* * *}$ & $(1.07)$ & $(-1.14)^{* * *}$ \\
& $.153^{*}$ & $0.365^{* * *}$ & $.192^{* * *}$ & $.139^{* * *}$ \\
Proportion of part-time students & $(2.19)$ & $(4.94)$ & $(5.73)$ & $(8.48)$ \\
& .0385 & $-0.0554^{*}$ & -.00712 & .0000159 \\
Full-time tenure-track union, $t-1$ & $(1.64)$ & $(-2.21)^{* *}$ & $(-0.63)$ & $(0.00)$ \\
& -.0555 & $-1.613^{* *}$ & -.00358 & .0410 \\
Full-time non-tenure track union, $t-1$ & $(-0.11)$ & $(-3.02)$ & $(-0.01)$ & $(0.33)$ \\
&. &. &. &. \\
Part-time non-tenure track union, $t-1$ &. &. &. &. \\
& -.0463 & -0.0704 & .00652 & .0208 \\
$N$ & $(-0.09)$ & $(-0.13)$ & $(0.03)$ & $(0.17)$ \\
\hline & 5392 & 5394 & 5394 & 5394 \\
\hline
\end{tabular}

Note: Year fixed effects are also included in all models; no bachelor's institution changed their full-time non-tenure track union status during the study period; t-values in parentheses; ${ }^{*} p<0.05$, ${ }^{* *} p<0.01,{ }^{* * *} p<0.001$ 